\title{
Effect of Selected Botanicals and Spinosad on Shoot and Fruit Borer (Leucinodes Orbonalis Gueene) and Natural Enemies in Brinjal Ecosystem
}

\author{
U. Sahana and Anoorag R. Tayde* \\ Department of Entomology, Naini Agricultural Institute, Sam Higginbottom University of \\ Agriculture, Technology and Sciences, Allahabad-211007(U.P.), India \\ *Corresponding author
}

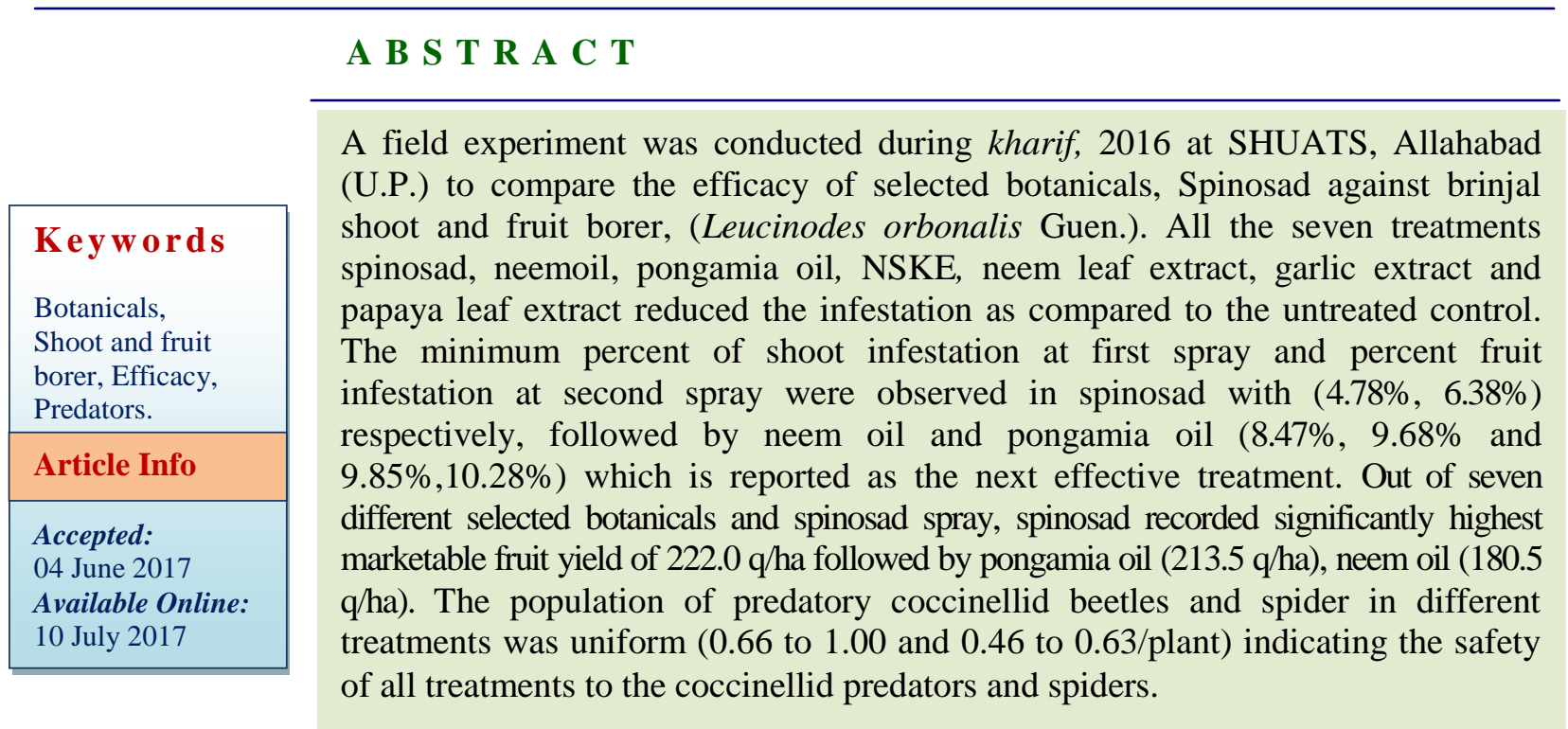

\section{Introduction}

Brinjal (Solanum melongena L.) crop is native to India and is grown throughout the country and around the year (Choudhary, 1970). It is one of the widely used solanaceous vegetable crops by people and is being cultivated in India for the last 4,000 years. Though brinjal is a summer crop, it is grown throughout the year under irrigated conditions. Hence, it is prone to attack by a number of insect pests right from nursery stage till harvesting (Regupathi et al., 1997). Among the major pests infesting brinjal the most important and destructive one is brinjal shoot and fruit borer (BSFB), Leucinodes orbonalis.
It is known to damage shoots and fruits of brinjal at all stages of plant growth. The caterpillar bores into the young growing shoots, petiole, midrib of the leaves and fruits leaving no sign of entry.

It riddles the plant part, feeds on the internal tissue causing the plants to fade and wither resulting into drying and dropping of growing shoots which is the typical symptom produced. Once the fruit setting begins, the caterpillar bores into the fruits by entering under calyx and feeds inside. The yield loss caused by BSFB could be as high as 70 per 
cent (Dhandapani et al., 2003) and may go up to 90 per cent as reported in India (Kalloo, 1988).

Although insecticidal control is one of the common means against the fruit borer, many of the insecticides applied are not effective in the satisfactory control of this pest. Brinjal being a vegetable crop use of chemical insecticides will leave considerable toxic residues on the fruits. Beside this sole dependence on insecticides for the control of this pest has led to insecticidal resistance by the pest (Natekar et al., 1987).

\section{Materials and Methods}

The trial was conducted in kharif, season 2016 the central research field, SHUATS, Allahabad (U.P.). Trial was laid out in a randomized block design consisting of seven different treatments. Each treatment was replicated thrice and brinjal variety Banarasi Gol was used for study.

Application of treatments for the management of the shoot and fruit borer was initiated as soon as 5\% ETL of shoot infestation observed in experimental field. Subsequent application was under taken at an interval of 15 days and two applications were made during experimental period. The data were subjected to statistical analysis. The yield per plot was also recorded. To assess safety of selected botanicals and spinosad against the natural enemies in brinjal ecosystem, the natural enemies count will be taken in all treatments

\section{Preparation of extracts}

Leaves of $A$. indica papaya, rhizome of garlic (A. sativum) were collected and shade - dried and were ground with a domestic grinder. Known quantity of well powdered leaf material was soaked in one-third of water and kept overnight. Stirring was done frequently.
Then the material was filtered through a clean muslin cloth and the clear filtrate was mixed with the remaining two-third portion of water.

\section{Results and Discussion}

Spinosad (6.38\%) was found to be effective against controlling the shoot infestation by shoot and fruit borer, L. orbonalis followed by Neem oil $(8.47 \%)>$ pongamia oil $(9.85 \%)$ $>$ NSKE $(11.19 \%)>$ Neem leaf extract $(12.42 \%)>$ Garlic extract $(12.09 \%)>$ Control $(18.47 \%)$ (Table 1). The statistical analysis of data showed that all the treatments are significantly effective. The treatments Garlic extract, pongamia oil, NSKE and Neem leaf extract were found to be non- significant but they were noted to have significantly reduced percent infestation than control. However, significant reduction in percent infestation was observed in Spinosad $\left(\mathrm{T}_{5}\right)$, when compared to all other treatments.

As far as fruit infestation was concerned Spinosad $(6.38 \%)$ showed the best result in controlling the fruit infestation and was significant to remaining treatment followed by other treatments.

The statistical analysis of data showed that all the treatments are significantly effective. The treatments, Neem oil, Garlic extract, pongamia oil, NSKE and Neem leaf extract were found to be non- significant but they were noted to have significantly reduced percent infestation than control.

Out of seven different selected botanicals and spinosad spray, Spinosad recorded significantly highest marketable fruit yield of $222.0 \mathrm{q} / \mathrm{ha}$. This was followed by Pongamia oil (213.5 q/ha), neem oil (180.5 q/ha), NSKE (150.0 q/ha), neem leaf extract (109.0/ha), garlic extract (69.0 q/ha) and papaya leaf extract (57.5 q/ha) were least effective in recording the marketable fruit yield. 
Table.1 Effect of botanicals and spinosad on shoot and fruit borer (Leucinodes orbonalis Gueene)

\begin{tabular}{|c|c|c|c|c|c|}
\hline \multicolumn{2}{|r|}{ Treatments } & $\begin{array}{l}\text { I Spray Shoot } \\
\text { infestation }(\%)\end{array}$ & $\begin{array}{l}\text { II Spray Fruit } \\
\text { infestation }(\%)\end{array}$ & $\begin{array}{c}\text { Mean } \\
\text { (Kg./Plot) }\end{array}$ & Yield (q/ha) \\
\hline $\mathbf{T}_{\mathbf{0}}$ & Untreated & $18.47^{\mathrm{a}}$ & $35.20^{\mathrm{a}}$ & $0.97^{\mathrm{a}}$ & 48.5 \\
\hline$\overline{T_{1}}$ & Neemoil 3\% & $08.47^{\mathrm{e}}$ & $09.66^{d}$ & $3.61^{\mathrm{de}}$ & 180.5 \\
\hline $\mathbf{T}_{2}$ & Garlic extract $50 \mathrm{ml} / \mathrm{L}$ & $12.09^{\mathrm{c}}$ & $12.91^{\mathrm{c}}$ & $1.38^{\mathrm{b}}$ & 69.0 \\
\hline $\mathbf{T}_{3}$ & Pongamia oil 3\% & $09.85^{\mathrm{d}}$ & $10.28^{\mathrm{d}}$ & $4.27^{\mathrm{e}}$ & 213.5 \\
\hline $\mathbf{T}_{4}$ & NSKE 5\% & $11.19^{\mathrm{cd}}$ & $12.20^{\mathrm{c}}$ & $3.0^{\mathrm{cd}}$ & 150.0 \\
\hline $\mathbf{T}_{5}$ & Spinosad $0.1 \mathrm{ml} / \mathrm{L}$ & $04.78^{\mathrm{f}}$ & $06.38^{\mathrm{e}}$ & $4.44^{\mathrm{e}}$ & 222.0 \\
\hline $\mathbf{T}_{6}$ & $\begin{array}{c}\text { Papaya leaf extract } \\
50 \mathrm{ml} / \mathrm{L}\end{array}$ & $15.11^{\mathrm{b}}$ & $16.17^{b}$ & $1.15^{\mathrm{a}}$ & 57.5 \\
\hline $\mathbf{T}_{7}$ & $\begin{array}{c}\text { Neem leaf extract } \\
50 \mathrm{ml} / \mathrm{L}\end{array}$ & $12.42^{\mathrm{c}}$ & $12.26^{\mathrm{c}}$ & $2.18^{\mathrm{bc}}$ & 109.0 \\
\hline \multicolumn{2}{|c|}{ F- test } & $\mathbf{S}$ & $\mathbf{S}$ & $S$ & $S$ \\
\hline \multicolumn{2}{|c|}{ S. Ed. $( \pm)$} & 0.57 & 0.46 & 0.45 & - \\
\hline \multicolumn{2}{|c|}{ C. D. $(P=0.05)$} & 1.24 & 1.01 & 0.97 & - \\
\hline
\end{tabular}

Table.2 Effect of selected botanical and spinosad on natural enemies (predators) in brinjal ecosystem

\begin{tabular}{|c|c|c|c|c|c|c|c|}
\hline \multirow{2}{*}{\multicolumn{2}{|c|}{ Treatments }} & \multicolumn{3}{|c|}{$\begin{array}{l}\text { Mean number of coccinellids/ } \\
\text { plant }\end{array}$} & \multicolumn{3}{|c|}{ Mean number of spiders/ plan } \\
\hline & & $\begin{array}{c}\text { 7days } \\
\text { after } \\
\text { I spray }\end{array}$ & $\begin{array}{c}7 \text { days } \\
\text { after } \\
\text { II spray }\end{array}$ & Mean & $\begin{array}{c}\text { 7days } \\
\text { after } \\
\text { I spray }\end{array}$ & $\begin{array}{c}7 \text { days } \\
\text { after } \\
\text { II spray }\end{array}$ & Mean \\
\hline $\mathbf{T}_{\mathbf{0}}$ & Untreated & $1.40^{\mathrm{a}}$ & $1.33^{\mathrm{a}}$ & $1.36^{\mathrm{a}}$ & 1.06 & 1.00 & 1.03 \\
\hline $\mathbf{T}_{1}$ & Neemoil 3\% & $0.73^{\mathrm{b}}$ & $0.86^{\mathrm{a}}$ & $1.00^{\mathrm{b}}$ & 0.48 & 0.73 & 0.55 \\
\hline $\mathbf{T}_{2}$ & $\begin{array}{l}\text { Garlic extract } \\
50 \mathrm{ml} / \mathrm{L}\end{array}$ & $0.86^{\mathrm{b}}$ & $1.00^{\mathrm{ab}}$ & $1.00^{\mathrm{b}}$ & 0.53 & 0.53 & 0.46 \\
\hline $\mathbf{T}_{3}$ & Pongamia oil 3\% & $0.80^{\mathrm{b}}$ & $0.93^{b}$ & $0.90^{\mathrm{bc}}$ & 0.60 & 0.66 & 0.50 \\
\hline $\mathbf{T}_{4}$ & NSKE 5\% & $0.93^{\mathrm{b}}$ & $0.73^{b c}$ & $0.90^{\mathrm{bc}}$ & 0.66 & 0.60 & 0.63 \\
\hline $\mathbf{T}_{5}$ & Spinosad 0.1ml/L & $0.66^{\mathrm{b}}$ & $0.86^{\mathrm{c}}$ & $0.86^{\mathrm{bc}}$ & 0.46 & 0.48 & 0.56 \\
\hline $\mathbf{T}_{6}$ & $\begin{array}{c}\text { Papaya leaf extract } \\
50 \mathrm{ml} / \mathrm{L}\end{array}$ & $1.00^{\mathrm{b}}$ & $1.06^{\mathrm{c}}$ & $0.76^{b c}$ & 0.53 & 0.93 & 0.60 \\
\hline $\mathbf{T}_{7}$ & $\begin{array}{c}\text { Neem leaf extract } \\
50 \mathrm{ml} / \mathrm{L}\end{array}$ & $0.93^{b}$ & $1.26^{\mathrm{c}}$ & $0.63^{\mathrm{c}}$ & 0.73 & 0.46 & 0.60 \\
\hline & F- test & $\mathbf{S}$ & $\mathbf{S}$ & $\mathbf{S}$ & NS & NS & NS \\
\hline & S. Ed. $( \pm)$ & 0.15 & 0.17 & 0.12 & 2.21 & 0.154 & 0.16 \\
\hline & C. D. $(P=0.05)$ & 0.31 & 0.35 & 0.30 & - & - & - \\
\hline
\end{tabular}


The statistical analysis of data showed that all the treatments are significantly recorded highest marketable yield compared to control. The treatments Neem oil, Garlic extract, pongamia oil, NSKE, Spinosad and Neem leaf extract were found to be non- significant but they were noted to have significantly recorded highest marketable yield than control. However, significant in recording highest marketable fruit yield was observed in Spinosad $\left(\mathrm{T}_{5}\right)$, when compared to all other treatments.

Budhvat and Magar (2014) revealed that lowest infestation (shoot and fruit infestation) and highest yield over control was observed in the treatment spraying of spinosad 45SC @ $0.01 \% \quad(256.71 \mathrm{q} / \mathrm{ha})$. Murugesan and Murugesh (2009) showed among the plant products, neem oil is able to reduce the shoot damage by more than 50 per cent during Kharif. The effectiveness of Spinosad against Leucinodes orbonalis, was reported by Deshmukh and Bhamare (2006) who claimed $08.33 \%$ infestation at the dose of Spinosad 50 SP@0.01\%.

The cumulative mean number of coccinellid predators/plant clearly indicated that all the treatments were completely safer $(0.63$ to $1.00 /$ plant) as they were statistically on par with untreated check (1.36). The cumulative mean number of spider/plant clearly indicated that all the treatments were completely safer ( 0.46 to $0.63 /$ plant) as they were on par with untreated check (1.03) (Table 2). At the end of imposition of all the treatments, it is clear from the results that all the treatments were found safer to the coccinellid and spiders.

Rosaih (2001) reported that botanicals in general and NSKE in particular were safe to the predators' viz., coccinellids, chrysopids, spiders and Apanteles in brinjal and okra ecosystem. Mittal and Ujagir (2005) recommended spinosad as safe insecticide to replace presently ineffective and harmful insecticides for natural enemies have been reported by above workers which agrees with the present findings.

\section{Acknowledgement}

We are grateful thanks to Director of Research who allotting field for this research work at central field of Sam Higginbottom University of Agriculture, Technology and Sciences, Allahabad, U.P.

\section{References}

Ashadul, M.I., Hussain, M.A., Shapla, S.A., Mehraj, H. and Jamal Uddin, F.M. (2014) Plant Extract for the Management of Brinjal Shoot and Fruit Borer (Leucinodes orbonalis Guenee). American-Eurasian, J. Agric. Environ. Sci., 14(12):1409-1414.

Budhvat, K.P. and Magar, P.N. (2014) Biorational management of Leucinodes orbonalis l.on brinjal J. Ind.Pollut.Contr. 30(2):255-258.

Choudhury, B. (1970) Vegetables. National book trust, New Delhi, 25-50.

Deshmukh, R.M. and Bhamare, V.K. (2006) Field evaluation of some insecticides against Brinjal shoot and Fruit borer, Leucinodes orbonalis Guen. J. Agric. Sci., 2(1): 247-249.

Dhandapani, N., Shelkar, U. R. and Murugan, M. (2003) Bio-intensive pest management in major vegetable crops: An Indian perspective. J. Food Agric. Environ., 1: 330-339.

Kalloo, G. (1988) Biochemical basis of insect resistance in vegetables. Vegetable Breeding, CRC Press Inc Boca Raton., 520-570.

Mittal, V. and Jagir, R. (2005) Toxicity of spinosad $45 \mathrm{SC}$ to natural enemies associated with insect pests of pigeonpea at Panthnagar. J. Biol. Contr. 19(1):73-76. 
Murugesan N. and Murugesh, T. (2009) Bioefficacy of some plant products against brinjal fruit borer, Leucinodes orbonalis Guenee (Lepidoptera: Pyrallidae), J. Biopesticides, 2(1): 60-63 Natekar, M. G., Samarjit rai and Agnihotri, N. P. (1987) Bioefficacy of synthetic pyrethroids and their residues in brinjal fruit. Pestology, 11: 18-22.

Rosaih, R. (2001) Performance of different botanicals against the pests' complex in bhendi. Pestology, 25: 17-19.

Regupathi, A., Palanisamy, S., Chandramohan, N. and Gunathilagaraj, K. (1997) A guide on crop pests. Sooriya Publishers, Coimbatore, 264.

\section{How to cite this article:}

Sahana, U. and Anoorag R. Tayde. 2017. Effect of Selected Botanicals and Spinosad on Shoot and Fruit Borer (Leucinodes Orbonalis Gueene) and Natural Enemies in Brinjal Ecosystem. Int.J.Curr.Microbiol.App.Sci. 6(7): 189-193. doi: https://doi.org/10.20546/ijcmas.2017.607.022 